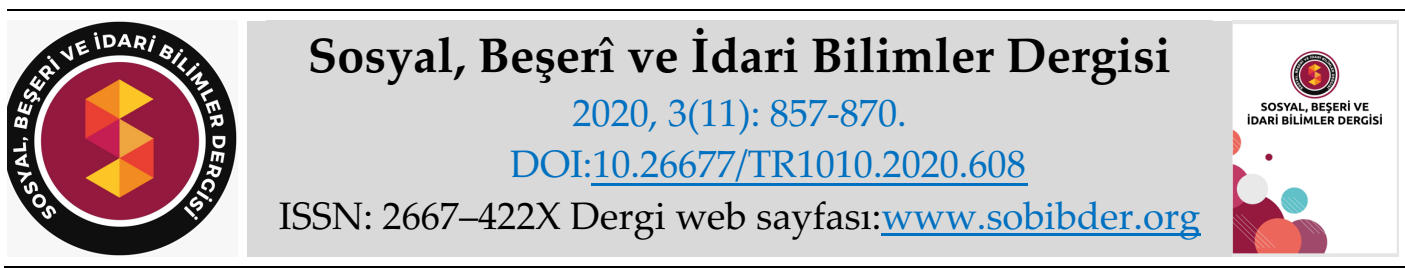

ARAŞTIRMA MAKALESI

\title{
Covid-19 Salgınının Yat Turizm İşletmecileri Tarafından Değerlendirilmesi: Marmaris Örneği
}

Dr. Öğr. Üyesi İsmail BİLGİÇLİ, Sakarya Uygulamalı Bilimler Üniversitesi, Karasu Meslek Yüksekokulu, Sakarya, e-posta: bilgicli@subu.edu.tr ORCID: https://orcid.org/0000-0003-1697-032X

Öğr. Gör. Dr. Recep YILDIRGAN, Sakarya Uygulamalı Bilimler Üniversitesi, Sapanca Turizm Meslek Yüksekokulu, Sakarya, e-posta: recepy@subu.edu.tr ORCID: https://orcid.org/0000-0002-9887-3883

Öz

Çin'in Wuhan şehrinde ortaya çıkan ve dünyanın tamamına yayılan Dünya Sağlık Örgütü tarafından Covid-19 (Yeni Tip Koronavirüs) adıyla belirtilen salgın tüm dünyada olduğu gibi Türkiye'de de turizm hareketlerini olumsuz etkilemiştir. Covid-19 salgını nedeniyle insan hareketlerinin durma noktasına gelmesi turizm endüstrisini ve dolayısıyla turizmde faaliyet gösteren diğer işletmeleri etkilemiştir. Bu araştırmanın amacı Türkiye'nin önemli bir turizm destinasyonu olan Marmaris'te faaliyet gösteren yat turizmi işletmelerinin Covid-19 salgınından nasıl etkilendiklerini, salgın ile ilgili süreci nasıl sürdürdüklerini ve geleceğe ilişkin salgın ile ilgili öngörülerini tespit etmek ve bu tespitler 1şı̆̆ında öneriler geliştirmektir. Araştırmada nitel araştırma yöntemlerinden faydalanılarak yat turizmi işletmecileri ile mülakatlar yapılarak elde edilen bilgiler değerlendirilmiştir. Araştırma sonuçlarına göre yat işletmecileri tüm diğer endüstri işletmeleri gibi Covid-19 salgınından ekonomik ve psikolojik olarak çok etkilendiklerini, gelir kaynaklarının kesilmesinden kaynaklı geleceğe dönük umutlarının belirsizleştiğini, sabit gider ödemelerinin devam etmesi nedeniyle zorlandıklarını, varlıklarını sürdürebilmede daha fazla destek gerektiğini belirtmektedirler.

Anahtar Kelimeler: Covid-19, Koronavirüs, Turizm, Yat Turizmi.

Makale Gönderme Tarihi: 13.07.2020

Makale Kabul Tarihi: 02.11 .2020

\section{Önerilen Atıf:}

Bilgiçli, İ. ve Yıldırgan, R. (2020). Covid-19 Salgınının Yat Turizm İşletmecileri Tarafından Değerlendirilmesi Marmaris Örneği, Sosyal, Beşeri ve İdari Bilimler Dergisi, 3(11): 857-870.

(C) 2020 Sosyal, Beşerî ve İdari Bilimler Dergisi. 


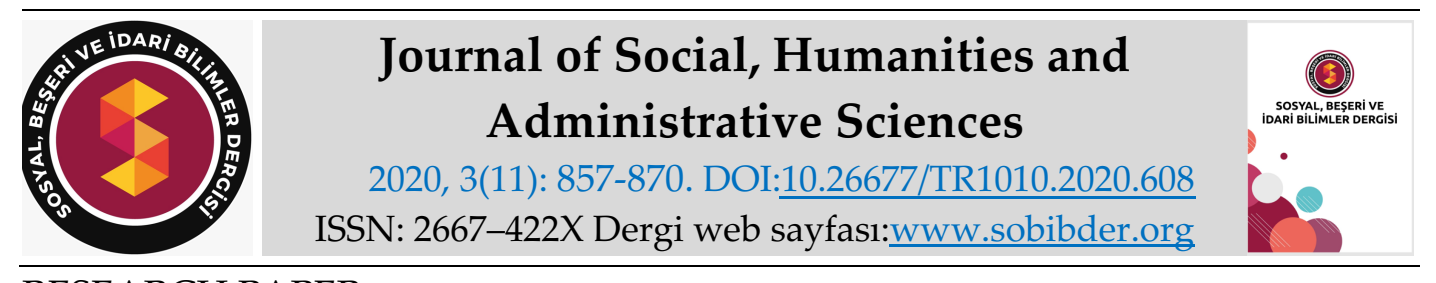

$\underline{\text { RESEARCH PAPER }}$

\title{
Evaluation of Covid-19 Outbreak by Yacht Tourism Operators: Example of Marmaris
}

Assistant Prof. Dr. İsmail BİLGİÇLİ, Sakarya University of Applied Sciences, Karasu Vocational School, Sakarya, e-mail: bilgicli@subu.edu.tr ORCID: https://orcid.org/0000-0003-1697-032X

Dr. Recep YILDIRGAN, Sakarya University of Applied Sciences, Sapanca Tourism Vocational School, Sakarya, e-mail: recepy@subu.edu.tr ORCID: https://orcid.org/0000-0002-9887-3883

\begin{abstract}
China's Wuhan city, and the resulting emitted by the World Health Organization to the entire world Covidien-19 (New Type coronavirus) is mentioned by name in Turkey as well as all over the world epidemic has adversely affected the tourism movement. The fact that human movements came to a halt due to the Covid-19 outbreak affected the tourism industry and therefore other businesses operating in tourism. The research objective of Turkey's most important tourism destination which lies operating in Marmaris tourism business of Covidien-19 how they are affected by the epidemic, and how they continue the process of dealing with the outbreak and to identify their predictions about the epidemic for the future and develop proposals on these findings light. In the research, using qualitative research methods, the information obtained by interviewing yacht tourism operators was evaluated. According to the results of the research, yacht operators stated that they were economically and psychologically affected by the covid-19 epidemic like all other industrial enterprises, their future hopes were uncertain due to the cut of their income sources, they were forced due to the continuation of fixed expense payments, and more support is needed to survive.
\end{abstract}

Keywords: Covid-19, Coronavirus, Tourism, Yacht Tourism.

Received: 13.07 .2020

Accepted: 02.11.2020

\footnotetext{
Suggested Citation:

Bilgiçli, İ. and Yıldırgan, R. (2020). Evaluation of Covid-19 Outbreak by Yacht Tourism Operators: Example of Marmaris, Journal of Social, Humanities and Administrative Sciences, 3(11): 857-870.

(C) 2020 Sosyal, Beşerî ve İdari Bilimler Dergisi.
} 


\section{Gíriş}

Dünyada sanayi devriminden sonraki süreçte oluşan ekonomik, sosyal ve kültürel değişimler insanların turizm ile ilgili istek ve ihtiyaçlarını oldukça etkilemiştir. Bu etkileşim turizmin uluslararası düzeyde yaygınlaşmasına neden olarak sanayi, tarım, ticaret gibi önemli bir endüstri olma özelliği kazanmasına neden olmuştur. Günümüzde turizm endüstrisi Türkiye gibi gelişmekte olan ülkeler başta olmak üzere tüm dünya ülkelerinin ekonomileri için giderek daha fazla önem kazanmaktadır. Turizm endüstrisi son yıllarda hızla gelişirken ülkelerin halklarının refah seviyelerinde meydana gelen değişimlere bağlı olarak turizme ayrılan harcama seviyeleri arttırılmıştır. Turizm harcamalarının artışı ile uluslararası toplumların kültürel iletişimi ve kaynaşması artmıştır.

Turizm bugün kapsadığı çok çeşitli iş alanları ve ekonomilerin kalkınma faaliyetlerine sağladığ yararlarla önemli bir hizmet endüstrisidir (Yağcl, 2003: 19). Turizm endüstrisinin özellikle istihdam, milli geliri arttırma ve dolayısıyla insanların yaşam standartlarını yükseltme ve etkileme gücü bulunmaktadır. Turizm endüstrisinin ekonomik etki gücü ülkeler tarafından anlaşıldıktan sonra turizmde daha hızlı bir gelişim süreci yaşanmıştır. Bu süreç günümüzde bazı ülkelerin sadece turizmden elde ettikleri kaynaklar ile ülke ekonomilerini sürdürmeleri sonucunu oluşturmaktadır. Dünya turizm örgütüne göre uluslararası turist sayısı 2018 yılında bir milyar dört yüz milyon kişiye, uluslararası turizm geliri ise bir trilyon üç yüz yirmi üç milyar dolara ulaşmıştır. Dünya, turizm ekonomisinden Türkiye 2019 yılında 51,7 milyon kişi turist ağırlayarak, 34,5 milyar dolar gelir elde etmiştir.

Çalışmada, dünya genelini etkisi altına alan Covid-19 salgınının oluşturduğu yaşam ortamları değişik yönleri ile incelenerek, Covid-19 pandemisi ve pandeminin turizm endüstrisindeki etkileri ile ilgili literatür taraması yapılmıştır. Bu araştırmada yarı yapılandırılmış mülakat yöntemi kullanılarak yat turizm işletmecileri ile görüşmeler yapılarak salgın ortamı, oluşturduğu yaşam standartları ve geleceğe yönelik öngörüleri hakkında düşünce ve değerlendirmelerini ortaya çıkarmaya yönelik yapılan alan araştırmasından elde edilen veriler incelenmiştir.

\section{COVID-19 KAVRAMSAL ÇERÇEVE}

Çin Halk Cumhuriyeti'nin Hubei eyaletine bağlı Wuhan'da Aralık 2019'da yeni bir koronavirüs nedeniyle gelişen pnömoni salgını kontrol altına alınamayarak kısa sürede Çin'in diğer eyaletlerine, sonra da bir pandemiye yol açacak şekilde başta Avrupa devamında Kuzey Amerika kıtası olmak üzere tüm dünyaya yayıldı. Eken virüs, önce yeni (novel) koronavirüs-2019 (2019-n $\mathrm{CoV}$ ), sonrasında Dünya Sağlık Örgütü (DSÖ) tarafından "Ciddi Akut Solunumsal SendromKoronavirüs 2" (Sars-CoV2) ve neden olduğu hastalık ise Covid-19 (Coronavirüs Disease 2019) olarak adlandırıldı (Aktoz vd., 2020: 2, Alimoğlu ve Erol, 2020: 102).

Dünya Sağlık Örgütü virüsün yayılma hızı, ciddiyeti ve yetkililerin gerekli önlemi almamasını gerekçe göstererek 12 Mart 2020'de Covid-19'u pandemik bir hastalık olarak ilan etti (Budak ve Korkmaz, 2020: 62, Arslan ve Karagül, 2020: 2). Koronavirüsler çeşitli canlı türlerini enfekte edebilirler. Hafif üst solunum yolu hastalıkları yanında ciddi akut solunum sendromu etkenidir. Bulaşma yolu solunum damlacıklarıyla ve doğrudan temasla olmaktadır (Hatipoğlu, 2020: 1). Dünyada toplum hayatı, sosyal mesafenin korunduğu ve kişiler arası temasın minimuma indirgendiği yeni normale doğru evrilmektedir. Covid-19 salgını nedeniyle insanlar yepyeni bir hayat tarzı ile karşı karşıya kaldılar. İlk vakaların görüldügüü ülkelerde acil olarak alınan tedbirler, insanları farklı bir durum ile karşılaşmanın ötesinde hayatlarını yeniden düzenlemek zorunda bırakmıştır (Bulut, 2020: 4). 
Çin'in Wuhan şehrinde artan oranda görülmeye başlayan pnömoni olgularında izole edilen salgın Covid-19 pandemisi olarak Dünya Sağlık Örgütü tarafından Ocak-2020'de duyurulmuştur (Karaca vd., 2020: 1). Koronavirüs hastalığ (Covid-19) 12 Mayıs 2020 itibariyle dört milyondan fazla kişiyi infekte etmiş ve üç yüz bine yakın insanın ölümüne neden olmuştur (Sandalcı, 2020: 1). Dünya genelinde yaygın bir pandemi oluşturan covid-19 salgını yaşamı ciddi anlamda tehdit etmeye devam etmektedir. Hastalık incelendiğinde sadece tıbbi boyutla sınırlı kalmayacağı, sosyokültürel, etik ve ahlak, hukuk, eğitim, turizm, ekonomi, tarım, halk sağlığı açısından olumsuz etkileri kaçınılmazdır (Üstün ve Özçiftçi, 2020: 142),

Koronavirüs, zamanı durdurdu, hayatımızın ayrılmaz bir parçası gibi gözüken pek çok şey (oyun parkları, kahveler, alışveriş merkezleri, üniversiteler, etkinlikler, toplantılar vb.) kısa sürede hayatımızdan çıtı (Yılmaz, 2020: 1). Koronavirüs hastalığı ile etkin mücadele eden devletler itibarlarını arttırırken diğerleri meşruiyet krizleri yaşayabilecektir (Okur, 2020: 311). Doğa, öngörülemez güçlerini sürekli olarak insanoğluna hatırlatmakta ve içinde yaşamış oldukları bu doğal çevre; sürekli olarak ve çoğu zamanda uyarmadan insanlar için tehlike oluşturan birçok salgını da ortaya çıkarmaktadır. Geçmişten geleceğe uzanan salgın hastalıkların, geçmişte ve günümüzde yaşandığı gibi, gelecekte de yaşanacak olması muhtemeldir. Uzak geçmişe gitmeden 21. yüzyılın ilk 20 yılında ortaya çıkan salgınlar bile, bulaşıcı hastalıklara karşı insanların ne kadar savunmasız olduğunu göstermeye yetmiştir (Budak ve Korkmaz, 2020: 63).

\section{COVİ-19 ve TURİM İLIŞKISİ}

Tüm dünyayı etkisi altına alan koronavirüs (Covid-19) salgını, en başta sağlık olmak üzere sosyal yaşamın tüm alanlarını, ekonomik yaşamı, bireylerin gündelik pratiklerini köklü bir biçimde etkilemiştir. Koronavirüs salgını dünya çapında milyonlarca insanın yaşam şeklini önemli ölçüde değiştiriyor ve bu değişimlerin çoğunun bir biçimde kalıcı olması bekleniyor. Çünkü salgın hastalıklar insanlık tarihi boyunca sadece yaşandıkları zaman toplumda büyük bir korku ve paniğe yol açmakla kalmamış, uzun vadede köklü toplumsal değişimlere yol açmıştır (Türkmen ve Özsarı, 2020: 55-61).

Özellikle insan hareketleri merkezli endüstrilerin bu salgın sürecini koordine etmekte epey zorlandıklarını söylemek gerekir. Turizm söz konusu olduğunda büyük ölçekli karantinalar, seyahat kısıtlamaları ve fiziksel mesafe önlemleri tüketicilerde bir düşüşe neden olmakta ve bu durum küresel ekonomik durgunluk yaratmaktadır (Özdemir, 2020: 224). Turizm sadece ekonomik yönden değil, aynı zamanda sosyokültürel yönden önemlidir (Aksu vd., 2014: 14). Ekonominin tüm endüstri alanlarında olduğu gibi, turizm endüstrisinin de kendine özgü bazı yapısal özellikleri mevcuttur (Bahar ve Kozak, 2018: 50). Turizm endüstrisinin temel kaynağ1 insan hareketinde itici güç olan güven ortamının oluşmasıdır. Turistler kendilerini ve çevresini güvenli bir ortamda tatil yaparken görmek için turizme katılmaktadır. Salgın hastalıkların söz konusu olduğu durumlarda doğal tepki gereği turistler satın almalarını iptal edeceklerdir. Covid-19 salgın sürecinde tüm dünya genelinde tur iptallerinin gerçekleşmesi ve oluşan panik havası en çok turizmi etkilemiştir.

Dünya Seyahat ve Turizm Konseyi (WTTC) tarafından yayınlanan 28 Nisan 2020 tarihli rapora göre salgının küresel ekonomi üzerindeki etkisi, 2008 küresel ekonomik krizinin etkisinden sekiz kat fazladır. Bunun nedeni ise 2020 yılında turizmde istihdamın \%31 oranında gerilemesi yani 100 milyon kişinin işini kaybetmesi ve turizm gelirinde \%30 oranında 2,7 trilyon dolar kaybın yaşanması olarak açıllanmaktadır (Özdemir, 2020: 224). Dünya ülkeleri birbiriyle daha bağlı ve entegredir. Covid-19 krizi, tedarik zincirleri boyunca yayılma etkileri yaratmakta ve aynı zamanda eşzamanlı olarak ortaya çıkan bir arz talep şoku söz konusudur. Ulaşım, eğlence, 
perakende, otel ve restoranlar gibi ülke ekonomilerinin neredeyse dörtte birini oluşturan kilit alanlar ciddi zararlar etmiş ve etmeye devam etmektedir (Cinel, 2020: 128).

Covid-19 salgınından en fazla etkilenen endüstri ise kuşkusuz turizmdir. Alınan tedbirler konaklama, seyahat, yiyecek ve içecek endüstrilerini doğrudan etkilemektedir. Restoran, lokanta ve kafelerin kapatılması, seyahat kısıtlaması sonrası otobüs ve uçak seferlerinin durdurulması, rezervasyonların ertelenmesi veya iptali, otellerde odaların boş kalması turizm için ciddi bir kayıptır. Dünya Turizm Örgütü (UNWTO) 2019 yılı verilerine göre dünyada 1,5 milyar kişi turizme katılırken, kısıtlama sebebiyle 2020 yılında \%20-\%30 seviyesinde turist varışlarının azalacağını öngörmektedir (Kıvılcım, 2020: 21). Turizm talebinin oluşmasında seyahatlerin sınırlandırılması, sağlık koşullarındaki değişiklikler gibi unsurlar en etkili faktörlerdendir (Yağcı, 2003: 26). Turizm talebini etkileyen ekonomi dışı diğer faktörler kategorisinde salgın hastalıklar önemlidir (Baytok vd., 2008: 88). Turizm ekonomisi açısından bakıldığında turizm talebi ile salgın hastalıklar arasında ters yönlü bir ilişki bulunmaktadır. Salgın hastalıklar arttığı veya ortaya çıktı̆̆ında turizm talebi azalacaktır. Turizm endüstrisi talebi lüks özellikli bir talep olarak algılandığı için, salgın hastalık, doğal afet ve terör gibi olaylardan çabuk etkilenerek talebi iptal etme ya da başka ihtiyaçlara yönlendirmeyi tercih edebilmektedir.

Küreselleşen dünya düzeninde sınırların ortadan kalkması, teknolojik ulaşım araçlarının yaygınlaşması, seyahatleri kolaylaştırırken, turizmin gelişmesini sağlamıştır. Fakat gelişen turizm endüstrisi salgın hastalıklar (Kuş gribi, Sars, Domuz gribi, Zika ve en son covid-19) gibi nedenlerden gelişimini yavaşlatmakta ve hedefler sekteye uğramaktadır. Covid-19 salgınının bütün turizm faaliyetlerini etkilemesi kaçınılmazdır. Turizm endüstrisi içerisinde faaliyet gösteren küçük ve orta ölçekli işletmelerde bu olumsuz etkilerin daha fazla hissedildiği tahmin edilmektedir (İbiş, 2020: 88). Kültür ve Turizm Bakanlığının 2019 ve 2020 yıllarında yayınlamış olduğu raporlara göre 2019 yılı birinci çeyreğinde ülkemize gelen toplam ziyaretçi sayısı 6,8 milyon olmuştur. Bir önceki yıla göre ziyaretçi sayısı \%7 oranında artmıştır. Ancak, koronavirüsün seyahat ve turizm üzerinde yaratmış olduğu olumsuz etkiler sonucunda 2020 yılı birinci çeyreğinde ülkemize gelen toplam ziyaretçi sayısı 2019 yılına göre \%20,5 azalarak 5,5 milyon seviyesine gerilemiştir (Cinel, 2020: 129).

Literatürü toparlamak gerekirse tüm çalışmaların oraya koyduğu tespitler; turizmin salgın hastalık gibi insan hareketlerini kısıtlayan oluşumlardan çok fazla etkilendiği, ekonomik olarak turizm endüstrisinden önemli katkılar sağlayan ülkelerin yanında, turizmden gelir elde eden diğer gelişmiş ülkelerinde salgının etkilerinin turizme yansımasından olumsuz yaralar alacağı şeklindedir. Turizm endüstrisinde insan hareketlerini sağlayan sağliklı ve güvenli ortamın varlığının, koronavirüs ve benzeri salgın hastalıkların oluşturduğu ortamlardan etkilenmemesi mümkün görünmemektedir. Literatür çalışmalarından çıkarılacak diğer bir konu ise, turizm endüstrisinin koronavirüs salgınından diğer endüstri alanlarına göre daha fazla etkilendiği ve etkilenmeye devam edeceği yönündedir.

\section{YÖNTEM}

Araştırmada Covid-19 salgınının Marmaris'te yat turizmi işletmecileri açısından oluşturduğu ortam, süreç ve sürecin sonunda beklentiler ve sorunların tespit edilmesi amaçlanmıştır. Nitel araştırma yöntemi çalışmada kullanılmıştır. Nitel araştırmaya uygun olması açısından derinlemesine incelemek amacıyla örneklem grubu oluşturularak çalışılmıştır. Veri toplama aşamasında yarı yapılandırılmış mülakat tekniği kullanılmıştır. Marmaris'te yatlarda ortalama 1500 kişi çalışırken, satış aşamasında 350-400 kişi çalışmakta, toplamda yaklaşık 2000 kişi yat turizminden gelir elde etmektedir. Bu evren içinden araştırmada özellikle temel sorunların ve 
sürecin etkilerinin doğru tespit edilmesi amacıyla işletme sahip ve yöneticileri ile görüşme yapılması hedeflenmiştir. Soru formunun oluşturulmasında araştırmacılar literatür taraması yaparak, güncel haber verilerinden yararlanılarak, araştırmanın amacına uygun form oluşturulmaya çalışılmıştır. Verilerin toplanması bizzat araştırmacıların sahada 19 yat turizmi işletmecisi ile 29 Temmuz 2020-5 Ağustos 2020 tarihleri arasında yüz yüze görüşülerek elde edilmiştir. Toplanan veriler betimsel analiz tekniğine uygun olarak, verilerin özgürlüğünü değiştirmeden katılımcıların söylemlerinin olduğu şekilde aktarıldığı tablolar ile odak noktaları tespit edilmeye çalışılmıştır.

\section{BULGULAR}

Araştırmaya katılan Marmaris'te yat turizmi işletmeciliği yapanların yaş durumları, cinsiyetleri, işletmelerinde çalışan sayıları, katılımcıların işletme pozisyonlarını ve iş tecrübelerini gösteren bilgiler Tablo 1'de verilmektedir.

Tablo.1 Katılımcıların Demografik Bilgileri

\begin{tabular}{|l|l|c|c|c|}
\hline Katılımcı & Yaş & Cinsiyet & Çalışan sayısı & $\begin{array}{c}\text { Pozisyon/İş } \\
\text { Tecrübesi }\end{array}$ \\
\hline K1 & 45 & E & 8 & Sahibi/21 \\
\hline K2 & 51 & E & 12 & Sahibi/18 \\
\hline K3 & 37 & E & 5 & Sahibi/16 \\
\hline K4 & 42 & E & 16 & Sahibi/10 \\
\hline K5 & 40 & K & 7 & Yönetici/13 \\
\hline K6 & 35 & E & 21 & Sahibi/10 \\
\hline K7 & 38 & K & 14 & Sahibi/23 \\
\hline K8 & 60 & E & 32 & Sahibi/24 \\
\hline K9 & 56 & E & 21 & Sahibibi/19 \\
\hline K10 & 50 & K & 11 & Sahibi/21 \\
\hline K11 & 43 & E & 17 & Sahibi/16 \\
\hline K12 & 58 & E & 6 & Sahibi/22 \\
\hline K13 & 38 & E & 20 & Sahibi/19 \\
\hline K14 & 45 & K & 10 & Yönetici/16 \\
\hline K15 & 47 & E & 13 & Sahibi/20 \\
\hline K16 & 51 & E & 17 & Sahibi/18 \\
\hline K17 & 49 & E & 7 & \\
\hline K18 & 44 & E & 9 & 11 \\
\hline K19 & 40 & E & & \\
\hline
\end{tabular}

Tablo 1'de verilen bilgilere göre katılımcı işletme sahibi ve yöneticilerin 35 ile 60 yaş grubu arasında oldukları, 15 adet katılımcının erkek, dört adet katılımcının ise bayan olduğu tespit edilmiştir. Çalışan sayılarına bakıldığında işletmelerin en az 5 en çok 32 kişi çalıştırdıkları tespit edilmiştir. Katılımcıların 16'sı işletme sahibi iken 3 katılımcı işletme yöneticisi pozisyonundadır. İş tecrübeleri açısından katılımcıların en az 10 yıl en çok 27 yıl tecrübeye sahip oldukları görülmektedir. Tablo verilerinin yaş açısından analizine göre yat turizm işletmecilerinin genellikle orta yaş grubu kişilerden oluştuğu görülmektedir. Buradan anlaşılan turizm endüstrisinde işletme sahip ve yöneticiliği için yeterli birikim ve güce sahip olabilmek için zaman gerekliliğini ortaya koymaktadır. Katılımcıların cinsiyetleri açısından verilere göre erkeklerin 
çoğunlukta (15) olduğu bir sahiplik ve yönetim olduğu görülmektedir. Çalışan sayılarına bakıldığında yat işletmelerinde çalışanların gerek satış ve diğer yan hizmetler olmak üzere hizmet aşamasının tüm alanlarında en az 5 kişi çalıştıran işletme olduğu gibi en çok 32 kişinin çalıştığı işletmelerin olduğu tespit edilmiştir. İstihdam açısından yat turizmi işletmelerinin Marmaris turizmine önemli katkılar sağladığı görülmektedir. Katılımcıların en az 10 yıllık en çok 24 yıllık iş tecrübelerine sahip olduğu yine katılımcıların dört tanesinin yönetici pozisyonunda kişiler kalan 15 katılımcının ise bizzat işletmelerin sahipleri olduğu görülmektedir. Çalışmanın isabetli veriler elde etmesi açısından işletme sahiplerinin katılımcı olmalarının birincil görüşlere ulaşma açısından önemli olduğu söylenebilir, Yine katılımcıların iş tecrübelerinin en az on yıllık olması turizm endüstrisinde hizmet kalitesi açısından önemli olabilir.

Tablo 2 verilerini oluşturmak için yöneticilere sorulan sırasıyla;

- “Salgının (Covid-19) Turizm endüstrisine etkisi hakkında kişisel görüşünüz nedir?”

- Salgının (Covid-19) Türkiye'de ne kadar süreyle etkili olacă̆ını düşünüyorsunuz?"

- “Salginın (covid-19) Türkiye'de ve konusunda ne düşünüyorsunuz?"

- “Salgın ile ilgili süreçte Türkiye'nin mücadelesinde kişisel görüşünüz nedir?"

sorulara verilen cevapların analizine göre oluşturulan odak noktaları Covid-19 salgın sürecinin turizmi çok büyük oranda etkilediği, salgının kısa sürede bitmeyeceği, bitme sürecinin aşı ve ilaç bulma çalışmaları ile ilgili olduğu, Türkiye'nin diğer ülkelere göre salgınla mücadelede daha iyi durumda olduğu yönündedir.

Tablo 3'te yat turizmi işletmecilerinden oluşan katılımcı grubuna Covid-19 Süreci ve Sonrasında Turizm işletmelerinin Faaliyetlerine İlişkin Görüşlerini değerlendirmeleri amacıyla sorulan sirasiyla;

- "salgın (Covid-19) sonrası Türkiye'deki turizm işletmelerinin faaliyetlerinde nasıl değişiklikler yapılacağını düşünüyorsunuz?"

- $\quad$ "Salgın (Covid-19) sonrası Türkiye'deki turizm işletmelerinin takip edecekleri süreçler izleyecekleri yol, yöntem ve uygulamalar konusunda fikirleriniz nelerdir?"

- "Salgın (Covid-19) Türkiye turizmine varsa faydaları konusunda görüşünüz nedir?"

- $\quad$ "Salgın (Covid-19) sürecindeki Türkiye'nin mücadelesinin potansiyel turizm pazarlarına doğru anlatılabildiği konusunda görüşünüz nedir?"

- "Salgın (Covid-19) sürecinde turizm işletmelerinin iç pazara yönelmelerini nasıl değerlendiriyorsunuz?"

- $\quad$ "Salgın (Covid-19) sürecinde Türkiye turizm işletmelerinin iç pazara yönelmesi yılı kurtarmalarında yeterli midir? Görüşünüz nedir?"

- "Salgin (Covid-19) sürecinde bulunduğunuz işletmenin almış olduğu tedbirler konusunda görüşünüz nedir?"

sorularına verilen cevaplardan tespit edilen odak noktalarına göre; işletmelerin hijyen ve sanitasyona daha fazla önem verdikleri, temizlik kuralları konusunda daha hassas davranışlar gösterdikleri, Salgında temizliğin öneminin bir kez daha hatırlandığı, salgınla mücadelenin potansiyel pazarlara doğru biçimde anlatıldığı, işletmelerin mecburen iç pazarlara yöneldiği, iç pazara yönelmenin işletmelerin mevcut yıllarını kurtarmaya yetmeyeceği ve işletmelerin aldığ tedbirlerin yeterli olduğu şeklindedir. 
Tablo. 2 Yat İşletmecilerinin Covid-19 Salgını, Etkileri, Süreç ve Sonrasına İlişkin Görüşleri

\begin{tabular}{|c|c|}
\hline Görüş (Doğrudan alıntılar) & Odak Noktalar \\
\hline 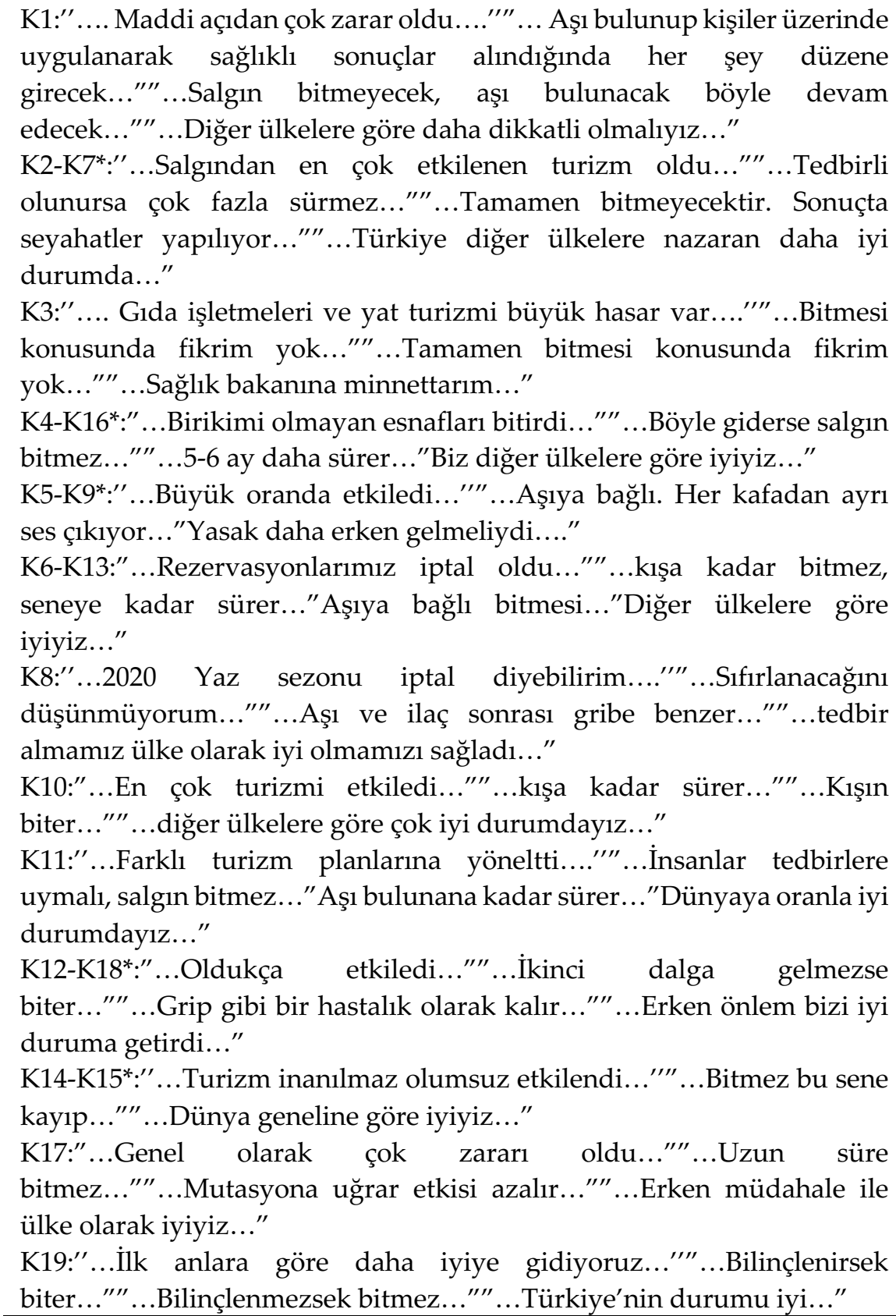 & $\begin{array}{l}\begin{array}{l}\text { Turizm en çok } \\
\text { etkilenen } \\
\text { endüstri... }\end{array} \\
\text { Kısa sürede salgın } \\
\text { bitmez... } \\
\text { Salgının bitme } \\
\text { süresi aşı ve ilaca } \\
\text { bağlı... } \\
\text { Türkiye diğer } \\
\text { ülkelere göre iyi } \\
\text { durumda.... }\end{array}$ \\
\hline
\end{tabular}

*Bazı katılımcılar aynı ifadeleri kullandıkları için tablo üzerinde birlikte gösterilmiştir. 
Tablo. 3 İşletmecilerin Covid-19 Süreci ve Sonrasında Turizm işletmelerinin Faaliyetlerine İlişkin Görüşleri

\begin{tabular}{|c|c|}
\hline Görüş (Doğrudan alıntılar) & Odak Noktalar \\
\hline 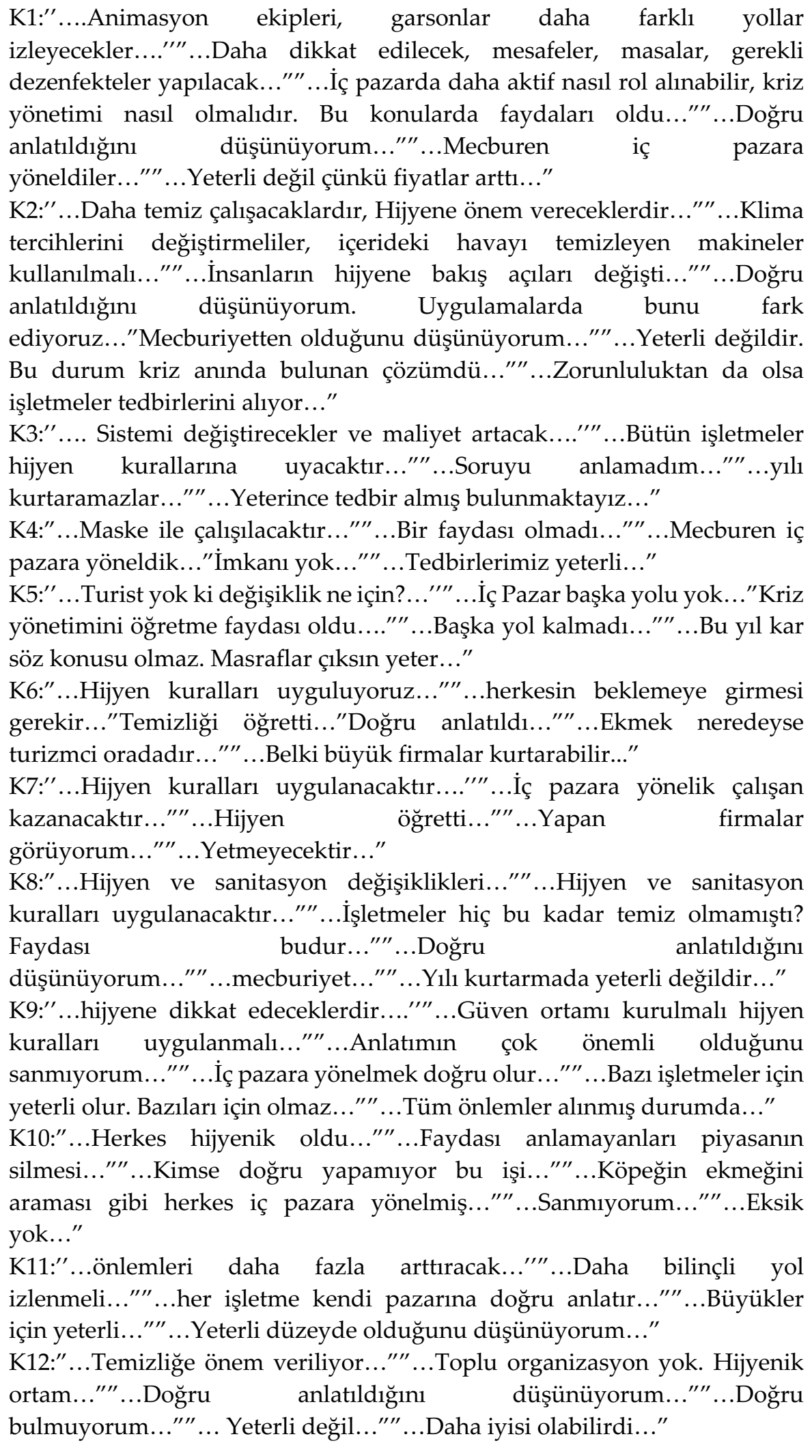 & $\begin{array}{l}\text { Hijyen ve } \\
\text { sanitasyona } \\
\text { daha fazla } \\
\text { önem } \\
\text { Temizlik } \\
\text { kurallarına } \\
\text { daha fazla } \\
\text { önem } \\
\text { Salgın } \\
\text { turizmde } \\
\text { temizliğin } \\
\text { önemini } \\
\text { hatırlattı } \\
\text { Salgın } \\
\text { mücadelesi } \\
\text { pazarlara } \\
\text { doğru } \\
\text { anlatılıyor. }\end{array}$ \\
\hline
\end{tabular}




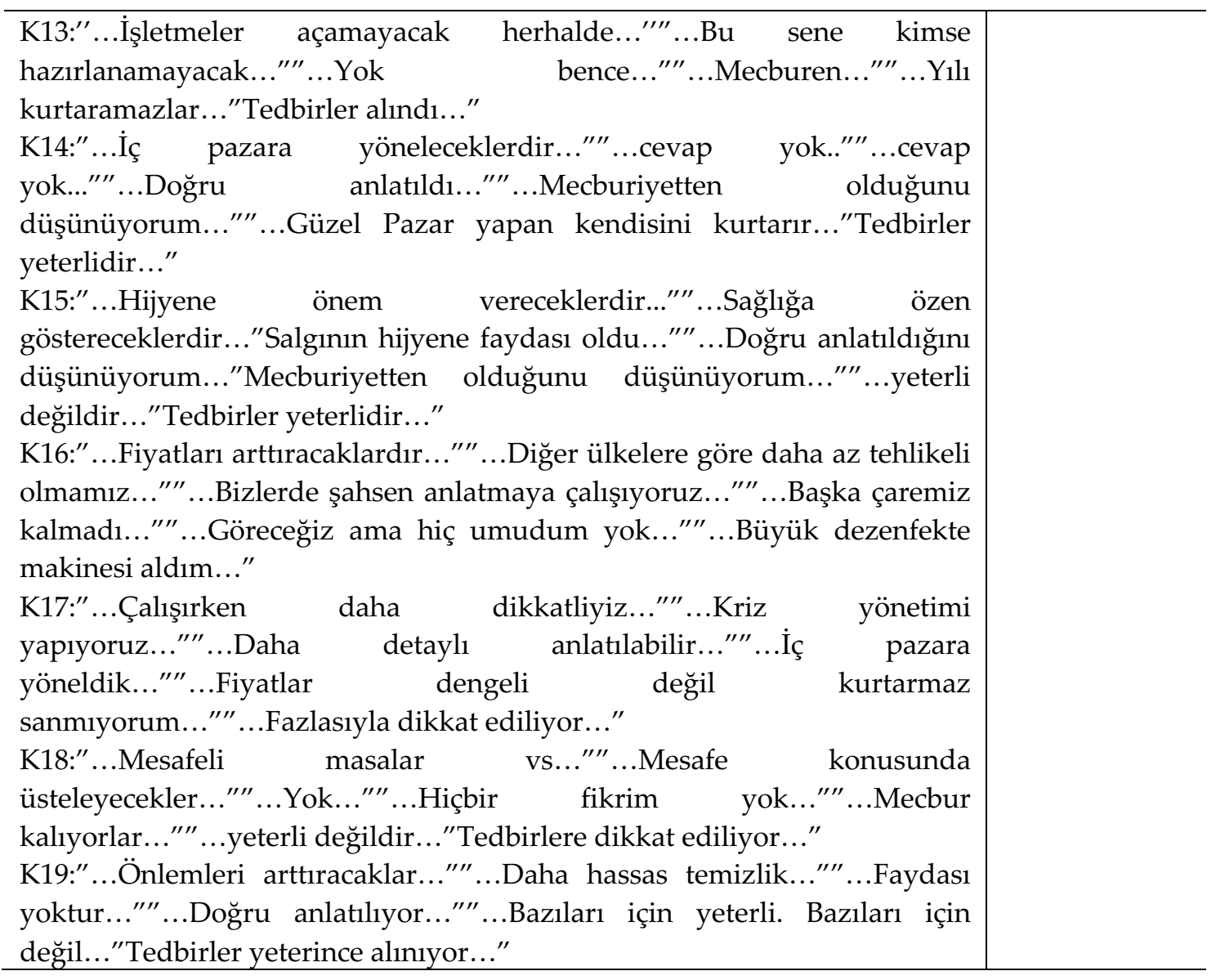

Tablo 4'te araştırma kapsamında katılımcı olan yat işletmecilerinin Covid-19 güvenlik sertifikasyonu, salgın tedbirleri, ve salgın eğitimine ilişkin görüşlerini tespit etmek amacıyla sorulan sirasiyla;

- "salgin Covid-19 sürecinde bulunduğunuz işletmenin almış olduğu sağlik sertifikasyonunun yeteli olduğunu düşünüyor musunuz?"

- "Salgın Covid-19sürecinde bulunduğunuz işletmenin departmanları arasında korona tedbirleri konusunda koordinasyonu nasıl değerlendiriyorsunuz?"

- "Salgın Covid-19 sürecinde işletmenizde çalışan personelin almış olduğu salgın eğitimini yeterli buluyor musunuz? İlave alınması gereken eğitimler var mıdır?"

sorulara verilen cevapların odak noktaları şöyle tespit edilmiştir. Katılımcılar salgın için alınan güvenlik sertifikasının yararll, gerekli ve yeterli olduğunu, tüm işletme çalışanlarının tam bir dayanışma ve takım ruhu içinde salgına karşı mücadele verdiklerini ve son olarak da personellerinin almış olduğu salgın eğitiminin yeterli olduğunu fakat rutin aralıklarla güncel bilgilerle yenilenmesinin yaralı olacağı şeklinde görüş bildirmişlerdir. Bazı sorular katılımcılar tarafından tam olarak anlaşılamadığından veya yorum yapmak istemediklerinden dolayı cevap verilmemiştir. 
Tablo. 4 Yat İşletmecilerinin Covid-19 Sertifikasyon, Tedbirler ve Salgın Eğitimine İlişkin Görüşleri

\begin{tabular}{|c|c|}
\hline Görüş (Doğrudan alıntılar) & Odak Noktalar \\
\hline 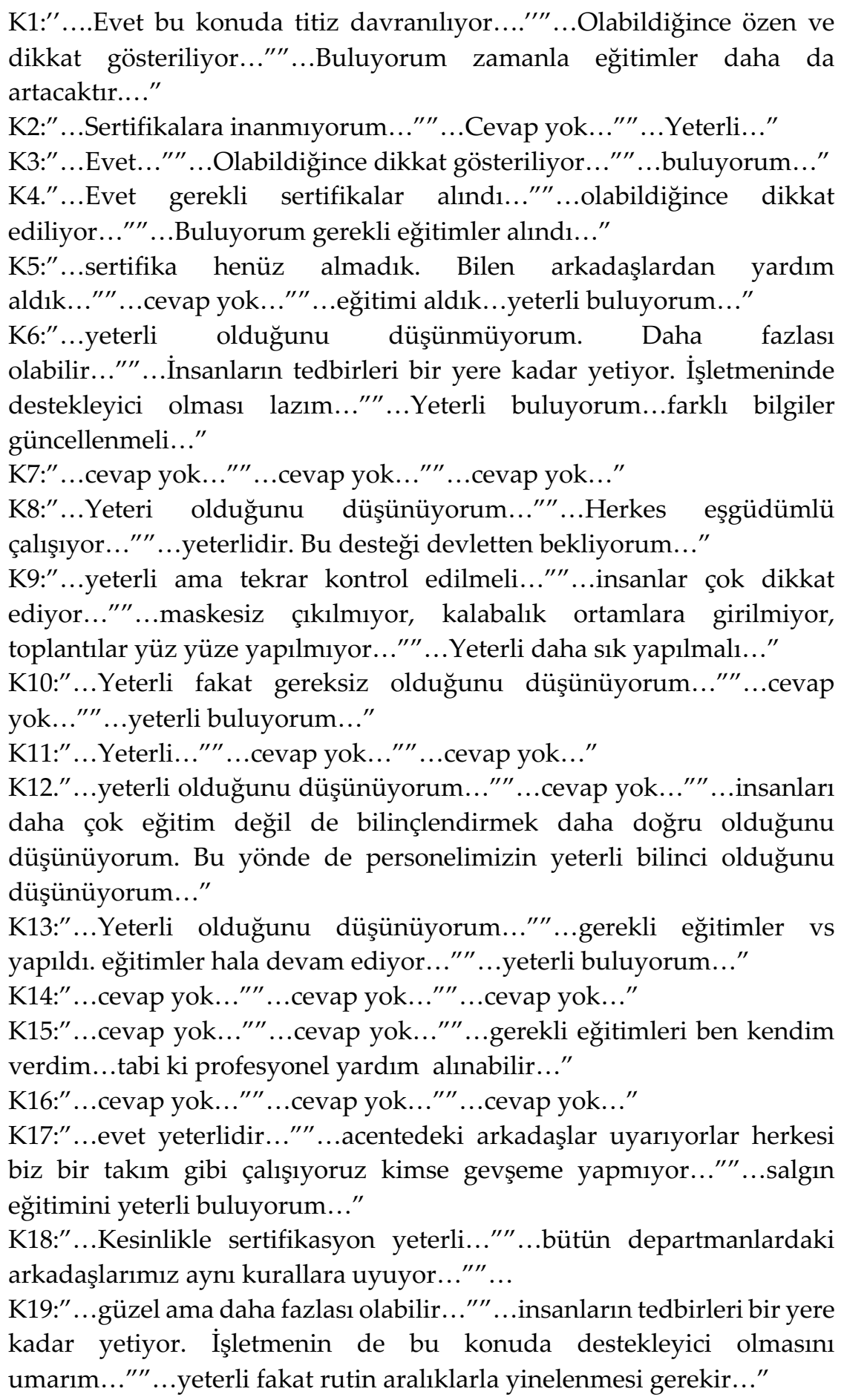 & $\begin{array}{l}\text { Tüm } \\
\text { işletme çalışanları } \\
\text { tam bir } \\
\text { dayanışma } \\
\text { içerisinde }\end{array}$ \\
\hline
\end{tabular}

Araştırma sonucunda; Türkiye'de faaliyet gösteren tüm turizm işletmeleri gibi araştırmada yer alan Marmaris'te yat turizm işletmeciliği yapan işletmeciler Coronavirüs salgınının oluşturduğu olumsuz ekonomik sonuçlardan etkilenmişlerdir. Yat turizm işletmelerinin olumsuz etkileri en aza indirecek işletme bazlı çabalarını ortaya koyarken devlet uygulamaları ile desteklenerek 
motivasyonlarının sağlanması yönünde önemli beklentileri bulunmaktadır. Yat turizm işletmelerinin yöneticileri olumsuz etkilerin salgın sürecinden sonra kısa sürede atlatılarak eski çalışma günlerine dönmelerinin uzun zaman alacağı yönünde beyanlarına rağmen umutlarının azalmadığı hatta bu durumdan ders çıkararak gelecek dönemlerde bu gibi durumlar için gereken kriz yönetimi hazırlıklarının yapılacağı beyanları önemlidir. Araştırma yapılması amacıyla yat turizm işletmelerinin yöneticileri ile görüşülmesinin dahi kendilerine motivasyon sağladığı, önemsendiklerini hissettikleri yönünde kayıt dışı ifadelerde bulunmuşlardır. Çalışmadan elde edilen önemli sonuçlardan bir diğeri de işletmelerin güvenli turizm sertifikasyonu gibi uygulamaların sadece salgın sürecinde değil salgın etkilerinin yok olmasından sonrada turizm işletmelerinin kullanmalarının önemli olacağı yönündedir. Bu tespitlerden anlaşılacağı üzere çalışmanın turizm işletmelerinin yöneticilerinin düşüncelerinin değerlendirilmesi açısından literatüre katkı sağlayacağı söylenebilir.

\section{SONUÇ ve ÖNERILER}

Covid-19 (Koronavirüs) salgını tüm dünyanın yaşam standartlarını felç eden, bilinenlerin farklı şekillerde yapılmasını sağlayan bir hastalık olurken, Türkiye'nin bu ortamdan etkilenmemesi mümkün değildir. Covid 19 salgınının tüm dünyada ekonomik ve sosyal yaşamı etkilemesi doğrultusunda, sosyal yaşamın en önemli uygulama alanı olan turizmin en çok etkilenen endüstri alanı olması kaçınılmaz bir son olmuştur. Günümüzde turizm destinasyonu olan ülkelerin, salgın nedeniyle oluşan hasarlarını tam olarak tespit edemez durumdadır. Etkilerin halen devam etmesi ve ne zaman biteceği ve yaraların ne zaman sarılacağı konusu kimse tarafından bilinememektedir. Dünyada sınırları ortadan kaldıran bu salgın tüm ülkelerin turizm sistemlerini, ekonomik sistemlerini ve psiko-sosyal yapılarını derinden etkilemiştir.

Dünyanın geçmişi ile ilgili yapılan tarihi araştırmalardan anlaşıldığına göre insanlık zaman zaman salgın hastalıklar ile büyük mücadelelere girişmiş, çok sayıda insan bu mücadelede hayatını kaybetmiştir. Buradan çıkan sonuç bu salgın bir ilk değil bir sonda olmayacaktır. Gelecekte olası bu ve benzeri durumların yaşanması muhtemel bir durum olarak görülmektedir.

Turizmde kalabalık gruplar halinde tatiller yerine yeni turizm uygulamaları, daha aile fertlerini kapsayacak izole turizm hareketleri tercih edilecektir. Doğal olarak sürdürülebilir turizm faaliyetleri kapsamında değişim ve yeniliklere ayak uyduracak, ayakta kalabilmek için maliyetlere katlanacak turizm işletmeleri varlıklarını devam ettirebileceklerdir. Turizm işletmelerinde hijyen, sanitasyon gibi uygulamalar daha fazla özen gösterilmesi ve uygulanması gereken sorumluluklar olarak sürdürülebilir işletmecilik anlayışının temelini oluşturacaktır.

Yat turizm işletmecileri ile yapılan çalışma neticesinde araştırmacıların bizzat yaşadığı ortamdan elde ettiği gözlemlere dayalı geliştirilebilecek öneriler şunlar olabilir;

Yat işletmecilerinin kredi ve borç ödemelerinin ertelenmesi, uzun vadeye yayılması, yeni kredi olanaklarının yapılacak banka anlaşmaları ile sağlanması.

Yat işletmecilerinin bu gibi durumlar için kriz yönetimi uygulamaları geliştirmeleri önerilir.

Yat işletmelerinde çalışanların istihdam desteği kapsamına alınması ve bu desteğin sürece bağlı olarak uzatılması gerekebilir.

İç pazara yönelen işletmelere tanıtım ve pazarlama konusunda destekler verilebilir.

Yat işletmelerinin çalışmalarından elde edilecek gelirlerde eşit dağıtım sistemi kurarlarsa rekabet ve huzursuzluk gibi çalışma yaşamını olumsuz etkileyen durumlar ortadan kalkabilir.

Havuz sistemi kurarak olası kötü durumlar için kaynak oluşturmada elde edilen gelirlerin bir 
kısmının ayrılması uygun olabilir.

Tüketici gruplarının farklılaştırılması için değişik ürün ve hizmetlerin geliştirilmesi sağlanabilir.

Çalışmada Covid-19 salgınından sonra yat turizmi işletmecilerinin aldığı önlemler, etkilendikleri durumlar, etkilenme konusundaki düşünceleri, gelecek ile ilgili öngörüleri ele alınmaktadır. Covid-19 ile ilgili kavramsal bir çalışmanın yanında alan araştırmasının bizzat katılımcı ile araştırmacının karşı karşıya gelerek yapması çalışmanın doğal ortam sonuçlarını yansıtması açısından önemlidir. Çalışma yat turizm işletmeciliğinin yapıldığı diğer turizm destinasyonlarında da uygulanabilir ve karşılaştırmalar yapılarak daha kapsamlı sonuçlar elde edilebilir. Salgının etkisinin yoğun olarak hissedildiği dönem yapılan çalışma, salgın sonrası farklılık gösterebileceği için salgından sonra çalışma tekrarlanarak sonuçlarının tekrar karşılaştırması yapılabilir. Turizm endüstrisinin dinamik yapısı gereği benzer çalışmaların ilerleyen zamanlarda yapılması sonucunda farklı veriler elde edilebilir.

\section{KAYNAKÇA}

Aksu, M. Çeltek, E. Koşan, A. Güler, G. E. Aşık, A. N. Sandıkçı, M. Avcı, M. Albayrak, A. Sarı, Y. Seçilmiş, C. Güzel, B ve Garda, B. (2014). Genel Turizm, Editörler: Özdipçiner, S ve Ayazlar, G. Lisans Yayınları, İstanbul.

Aktoz, M. Altay, H. Aslanger, E. Atalar, E. Atar, İ. Aytekin, V. Baykan, O. A. Barçın, C. Barış, N. Boyacı, A. A. Çavuşoğlu, Y. Çelik, A. Çinier, G. Değertekin, M. Demircan, S. Ergönül, Ö. Ertürk, M. Erol, K. Görenek, B. Gürsoy, O. M. Hünük, B. Kahveci, G. Karabay, Y.C. Karaca, I. Kayıkçıŏlu, M. Keskin, M. Kılıç, T. Avcı, K. B. Kırma, C. Kocabaş, U. Kocakaya, D. Küçükoğlu, S. Mutlu, B. Nalbantgil, S. Okuyan, E. Okyay, K. Özen, K. D. Özgül, S. Özpelit, E. Pirat, B. Sert, S. Sinan, Y. Ü. Şener, Z. Y. Tatlı, E. Tekkeşin, İ. A. Tutar, E. Ural, D. Yıldırımtürk, Ö ve Yıldızeli B. (2020). Türk Kardiyoloji Derneği Uzlaşı Raporu: COVID-19 Pandemisi ve Kardiyovasküler Hastalıklar Konusunda Bilinmesi Gerekenler, Türk Kardiyoloji Derneği. 48:1-87. Doi:10.5543/tkda.2020.36713.

Alimoğlu, O ve Erol, I. C. (2020), Covid-19 Pandemisi Sırasında Genel Cerrahi Uygulamalarına Yaklaşım. Anadolu Kliniği Tıp Bilimleri Dergisi, 25(1):102-110.

Arslan, İ ve Karagül, S. (2020). Küresel Bir Tehdit (Covid-19 Salgını) ve Değişime Yolculuk. Üsküdar Üniversitesi Sosyal Bilimler Dergisi. 10, 1-36. Doi: 10.32739/uskudarsbd.6.10.67.

Bahar, O. ve Kozak, M. (2018). Turizm Ekonomisi, Detay Yayıncılık, Ankara.

Baytok, A. Gül, K. Mankan, E. Bilgiçli, İ. Caber, M. Kızanlıklı, M ve Şahin, T. (2008). Turizm Ekonomisi, Editörler: Selçuk, N, G ve Şahin, T, Lisans Yayınları, İstanbul.

Budak, F.ve Korkma, Ş. (2020), Covid-19 Pandemi Sürecine Yönelik Genel Bir Değerlendirme: Türkiye Örneği. Sosyal Araştırmalar ve Yönetim Dergisi, 1, 62-79.

Bulut, M. (2020). Effects of New Normal Life on Electricity Consumption in Covid-19 Process. Journal of Scientific, Technology and Engineering Research, 1(1):4-6. Doi:10.5281/zenodo.39028885.

Cinel, A. E. (2020). Covid-19'un Küresel Makroekonomik Etkileri ve Beklentiler, Politik Ekonomik Kuram, 4 (1), 124-140.

Hatipoğlu, N. (2020). İnsanlığın “Yeni” Sorunu: Yeni Koronavirüs (2019-nCoV/Covid-19) Hastalığ 1 Medikal Journal of Bakırköy, 16(1), 1-8. Doi: 10.5222/BMJ.2020.22931.

İbiş, S. (2020). Covid-19 Salgınının Seyahat Acentaları Üzerine Etkisi, Safran Kültür ve Turizm 
Araştırmaları Dergisi, 3(1): 85-98.

Karaca, S. A. Özmen, M. M. Uçar, D. A. Yastı, Ç. A ve Demirer, S. (2020). Covid-19'lu Hastalarda Genel Cerrahi Ameliyathane Uygulamaları. Derleme Türk J Surg. 36(1):5-10, Doi: 10.5578/turkjsurg.202002.

Kıvılcım, B. (2020). Covid-19 (Yeni Koronavirüs) Salgınının Turizm Sektörüne Muhtemel Etkileri, Uluslararası Batı Karadeniz Sosyal ve Beşeri Bilimler Dergisi, 4(1):17-27. Doi.org/10.46452/baksoder.727208

Okur, A. M. (2020). Covid-19 Salgını, Dünya Düzeni ve Türkiye. Akademik Hassasiyetler. (7), 13: 311-335.

Özdemir, A. (2020). Covid-19 Salgını Sonrası Alınan Önlemlerle Turizm: Muhtemel Senaryolar. Journal of Recreation and Tourism Research/JRTR 7 (2), 222-238. Doi: 10.31771/jrtr.2020.62.

Sandalcı, B. Uyaroğlu, A. O. ve Güven, S. G. (2020). Covid-19'da Kronik Hastalıkların Rolü, Önemi ve Öneriler. Flora Derleme. 25(5) Doi: 10.5578/flora.69700, 1-7.

Türkmen, M ve Özsarı, A. (2020). Covid-19 Salgını ve Spor Sektörüne Etkisi, International Journal of Sport Culture and Science, 8(2), 54-67. Doi:10.14486/intjscs.2020.596.

Üstün, Ç. ve Özçiftçi, S. (2020). Covid-19 Pandemisinin Sosyal yaşam ve Etik Düzlem Üzerine Etkileri: Bir Değerlendirme Çalışması. Anadolu Klinĭği Tıp Bilimleri Dergisi, 25 (1), 142-153. Doi: 10.21673/anadoluklin.721864,

Yağcl, Ö. (2003), Turizm Ekonomisi, Detay Yayıncılık, Ankara.

Yılmaz, S. (2020). Covid-19'u Kim Üretti? Aşı ne Zaman Bulunacak?abcgazetesi.com/yazarlar/prof-dr-sait-yilmaz/covid-19u-kim-uretti-asisi-ne-zamanbulunacak-93369.E.T: 12.08.2020. 